\title{
PENGARUH PENERAPAN CORPORATE SOCIAL RESPONSIBILITY TERHADAP PROFITABILITAS PERUSAHAAN MANUFAKTUR DI BURSA EFEK INDONESIA TAHUN 2013-2017
}

\author{
Kleysia N. Tanod ${ }^{1}$, Grace B. Nangoi ${ }^{2}$, I Gede Suwetja ${ }^{3}$ \\ 1,2,3 Jurusan Akuntansi, Fakultas Ekonomi dan Bisnis Universitas Sam Ratulangi, J1. Kampus Bahu, Manado, \\ 95115, Indonesia \\ Email : Kleysianatalia@gmail.com
}

\begin{abstract}
Corporate Social Responsibility is a form of corporate responsibility towards shareholders, parties with an interest in the company and the community. CSR is also an important factor that is the basis for investors' consideration to make investment decisions on the company so that the company can manage investor capital to carry out company activities to achieve profits. This study aims to determine the effect of corporate social responsibility on corporate profitability, this study uses the ratio of return on assets and return on equity to calculate the company's profitability. This research uses quantitative research method with simple linear regression, where this study uses only 1 independent variable and 2 dependent variables. The population use in this study are manufacturing company listed on the Indonesia Stock Exchange in 2013-2017. The sample of this study used 59 manufacturing companies that met the sample selection criteria. Sample selection uses purpose sampling technique. The results show that corporate social responsibility has a significant effect on return on assets and return on equity.
\end{abstract}

Keywords: Return on Equity, Corporate Social Responsibility, Profitability, Return on assets

\section{PENDAHULUAN}

Ada berbagai cara dalam perusahaan untuk menghasilkan laba, salah satu cara yang dapat mempengaruhi profitabilitas adalah melalui pengungkapan Corporate Social Responsibility. Corporate Social Responsibility adalah salah satu bentuk tanggung jawab perusahaan terhadap masyarakat di sekitar perusahaan serta terhadap para konsumen perusahaan mengenai akibat-akibat yang berhubungan dengan kegiatan produksi perusahaan. Perusahaan dianggap sebagai salah satu yang merusak lingkungan hingga mengakibatkan terjadinya bencana. Maka dari itu perusahaan bertanggung jawab untuk menciptakan lingkungan yang bebas bencana dan layak untuk ditinggali. Perusahaan yang melakukan program tanggung jawab sosial akan bertahan lebih lama.

Bentuk tanggung jawab yang dilakukan oleh perusahaan bermacam-macam, yaitu dengan mengelola limbah dan pemakaian energi perusahaan, menanam pohon bersama dengan masyarakat sekitar lingkungan perusahaan untuk mengurangi sebagian dampak negatif dari globalisasi, memberikan beasiswa kepada masyarakat sekitar perusahaan yang kurang mampu, memberikan sumbangan kepada masyarakat yang terkena bencana alam, mendirikan pusat pelatihan sebagai pemberdayaan masyarakat serta perbaikan sarana dan prasarana yang rusak dan lain-lain. Profit atau laba menjadi salah satu tujuan dalam perusahaan, dan kemampuan perusahaan dalam mengumpulkan profit disebut profitabilitas. Pengungkapan tanggung jawab perusahaan dapat mempengaruhi profitabilitas perusahaan, karena semakin banyak item yang diungkapkan atau dilakukan oleh perusahaan maka akan membangun brand image dalam masyarakat. Sehingga perusahaan makin terkenal dikalangan masyarakat. 


\section{TINJAUAN PUSTAKA}

Pengertian Akuntansi. Riwayadi (2014:24) Akuntansi merupakan suatu proses untuk mentransformasi input menjadi output. Input-nya adalah data akuntansi dan output-nya adalah informasi akuntansi. Data akuntansi dapat berupa data keuangan dan nonkeuangan.

Pengertian Akuntansi Manajemen. Halim (2013:3) Akuntansi Manajemen diartikan sebagai suatu kegiatan atau proses yang dapat menghasilkan informasi-informasi tentang keuangan untuk manajemen dalam pengambilan keputusan ekonomi saat melaksanakan fungsi manajemen.

Pengertian Corporate Social Responsibility. Filemon (2014:225) Corporate social responsibility (CSR) dapat diartikan suatu tindakan yang bias mengembangkan masyarakat dan bertanggung jawab kepada tindakan yang berisi keterlibatan beberapa orang, lingkungan dan komunitas.

Pengertian Profitabilitas. Rifqiyah (2016:3) Profitabilitas adalah suatu kemampuan organisasi atau perusahaan dalam hal mendapatkan keuntungan atau laba serta memperlihatkan besar atau tidaknya usaha dan kerja keuangan organisasi atau perusahaan untuk mendapatkan laba.

Rasio Profitabilitas. Rasio profitabilitas yang dapat digunakan dalam penelitian ini adalah Return on Asset (ROA) dan Return on Equity (ROE).

Pengertian return on asset. Fitria (2014:4) return on asset merupakan suatu rasio yang dipakai dalam hal menghitung kemampuan organisasi atau perusahaan secara keseluruhan dalam hal mengumpulkan profit dalam jumlah keseluruhan harta atau asset yang tersedia didalam perusahaan.

Pengertian return on equity. Fitria (2014:4) return on equity dapat diartikan sebagai perhitungan penghasilan yang diperuntukkan buat pemilik-pemilik organisasi atau perusahaan untuk uang yang diinvestasikan sebagai modal oleh pihak yang berada dalam perusahaan.

\section{METODE PENELITIAN}

Jenis Penelitian. Pada penelitian ini penulis menggunakan penelitian bentuk kuantitatif yaitu metode yang digunakan dalam penelitian yang menggunakan populasi dan sampel sebagai hal yang diteliti.

Tempat dan Waktu Penelitian. Lokasi peneletian dilakukan di Bursa Efek Indonesia dalam bentuk pengumpulan data laporan keuangan perusahaan manufaktur yang tercatat pada tahun 2013 - 2017. Waktu penelitian adalah pada bulan Agustus-Oktober 2018.

Populasi dan Sampel. Populasi pada penelitian ini menggunakan semua perusahaan manufaktur yang tercatat secara konsisten di Bursa Efek Indonesia (BEI) dari tahun 2013 2017.

Metode Sampling. Metode sampling yang dipakai pada penelitian saat ini yaitu non probability sampling dan menggunakan teknik purpose sampling (pengambilan sampel disengaja). Purpose sampling adalah teknik pengambilan sampel yang ditentukan dengan beberapa pertimbangan tertentu. Penelitian ini menggunakan beberapa pertimbangan dengan beberapa kriteria seperti dibawah ini:

a. Perusahaan Manufaktur yang tercatat di Bursa Efek Indonesia (BEI) secara konsisten untuk periode 2013 - 2017.

b. Perusahaan yang mempublikasikan laporan keuangan tahunan dan annual report secara berturut-turut untuk periode 2013 - 2017.

c. Perusahaan yang mempunyai laporan keuangan dengan periode yang berakhir setiap 31 desember secara konsisten untuk periode 2013 - 2017.

d. Perusahaan menggunakan mata uang rupiah dalam laporan keuangannya secara konsisten untuk periode 2013 - 2017. 
e. Perusahaan mengungkapkan tanggung jawab sosial secara konsisten untuk periode 2013 2017.

Jenis Variabel. Terdapat 2 jenis variabel yaitu variabel independen serta variabel dependen. Variabel dependen pada penelitian saat ini adalah Profitabilitas yang dapat diukur dengan rasio ROA juga ROE, serta variabel independen dalam penelitian ini adalah Corporate Social Responsibility.

Definisi dan Pengukuran Variabel. Variabel dependen yaitu Profitabilitas adalah kemampuan perusahaan untuk menghasilkan profit. Dalam penelitian ini profitabilitas diukur dengan menggunakan ROA dan ROE dengan menggunakan rumus seperti berikut:

$$
\begin{gathered}
\text { ROA }=\frac{\text { Net Income }}{\text { Total Aset }} \times 100 \% \\
\text { ROE }=\frac{\text { Laba bersih sesudah pajak }}{\text { Modal Sendiri }} \times 100 \%
\end{gathered}
$$

Sementara itu variabel independen yaitu Corporate Social Responsibility diukur dengan membandingkan jumlah item yang diterapkan perusahaan dalam periode waktu tertentu dengan jumlah item yang diharapkan untuk tiap perusahaan. Variabel ini menggunakan 78 item pengungkapan CSR oleh Sembiring (2005) dengan rumus Corporate Social Responsibility $=\mathrm{n} / 78$.

Jenis data. Jenis data yang dipakai pada penelitian saat ini merupakan data yang berbentuk kuantitatif, karena hanya informasi yang berupa angka yang dijadikan data untuk dianalisis peneliti.

Sumber data. Sumber data yang digunakan dalam penelitian ini adalah data sekunder. Karena peneliti memperoleh data tersebut bukan dari hasil wawancara dan survey langsung melainkan dari laporan tahunan (annual report) perusahaan yang dipublikasi oleh websitu Bursa Efek Indonesia (BEI).

Metode pengumpulan data. Supaya didapat data yang bisa diketahui faktanya serta lengkap, maka dari itu penelitian pada saat ini memakai metode pengumpulan data dengan cara mengakses website dan situs-situs yang menyediakan informasi sehubungan dengan masalah dalam penelitian, dan penelitian perpustakaan (library research) yang berguna untuk mendapatkan landasan teoritis untuk melaksanakan penelitian.

Metode dan proses analisis. Dalam penelitian ini data yang diperoleh dari laporan keuangan yang dipublikasikan di Bursa Efek Indonesia akan ditabulasi dengan menggunakan analisis statistic dengan program komputer SPPS versi 24. Data yang terkumpul akan dianalisis dengan beberapa tahap, yaitu analisis deskripsi data, uji asumsi klasik meliputi dari uji heteroskedastisitas, uji multikolonearitas, uji normalitas dan uji autokorelasi, serta uji hipotesis.

Metode dan Proses Analisis. Data dalam penelitian ini didapatkan dari laporan-laporan keuangan yang dipublikasikan di BEI yang ditabulasi dengan menggunakan analisis statistik dengan aplikasi SPSS versi 24. Data yang berhasil dikumpulkan akan dianalisis dalam beberapa tahap, seperti analisis deskripsi data, uji asumsi klasik, dan uji hipotesis.

Analisis Statistik Deskriptif. Sugiono (2016:199) menyatakan bahwa analisis deskriptif merupakan metode statis agar bisa dipakai dalam hal menganalisis data untuk menjelaskan suatu data yang dikumpulkan apa adanya dengan tidak mempunyai maksud untuk menghasilkan keputusan yang bersifat umum.

Uji Asumsi Klasik. Uji asumsi klasik dalam hal ini memiliki tujuan mencari tahu tentang distribusi data, hubungan dalam variabel independen serta konsistensi varian 
pengganggu. Dalam penelitian ini uji asumsi klasik yang dipakai yaitu uji normalitas, uji multikolonearitas, uji heteroskedastisitas serta uji autokorelasi.

Uji Normalitas. Priyatno (2016:118) uji normalitas dalam penelitian ini berguna dalam hal mencari tahu tentang suatu model regresi,serta mengetahui apakah nilai residual mempunyai distribusi normal ataupun tidak normal. Residual sendiri mempunyai arti sebagai perbedaaan nilai pada variabel $\mathrm{Y}$ dan variabel $\mathrm{X}$ yang di prediksikan. Jikalau asumsi ini di langgar maka uji statistik tersebut akan menjadi tidak valid pada jumlah sampel yang kecil.

Uji Multikolonearitas. Ghozali (2013:105) menyatakan uji multikolonearitas memiliki tujuan dalam menguji model regresi apakah ditemukan korelasi antara variabel bebas (independen). Suatu model regresi pada dasarnya tidak menimbulkan korelasi antar variabel independen. Jikalau variabel independen tersebut berkorelasi satu sama lain independen yang nilai korelasi antar sesama variabel independen sama dengan nol.

Uji Heteroskedastisitas. Priyatno (2016:131) heteroskedastisitas adalah keadaan dimana terjadinya ketidaksamaan varian dari residual pada model regresi.

Uji Autokorelasi. Priyatno (2016 :139) menyatakann bahwa autokorelasi merupakan suatu posisi dimana ditemukan korelasi yang berasal dari residual yang bertujuan sebagai proses pengamatan masing-masing yang diurut sesuai waktu.

Uji Koefisien Regresi. Priyatno (2016:47) menyatakan bahwa uji ini bertujuan dalam hal menebak atau meramalkan apakah terjadi perubahan pada nilai variabel dependen apabila variabel independen mengalami perubahan.

Uji Koefisien Korelasi. Tujuan dari uji ini adalah mengetahui ukuran kekuatan linier antar variabel dependen dan variabel independen.

Uji Koefisien Determinasi. Digunakan untuk mengetahui seberapa besar variabel independen dalam menjelaskan variasi variabel dependen.

Uji Signifikansi Parsial (Uji T). Priyatno (2016:73) Uji T bebas digunakan untuk menguji perbedaan antara rata-rata dari dua kelompok sampel yang independen. Suatu dasar dalam pengambilan keputusan pada Uji T:

1. $\mathrm{H} 0$ di terima dan $\mathrm{H} 1$ di tolak jika nilai t hitung $<\mathrm{t}$ tabel atau jika nilai Sig $>0,05$

2. H0 di tolak dan H1 di terima jika nilai t hitung $>\mathrm{t}$ tabel atau jika nilai Sig $<0,05$

Perumusan Hipotesis

a. Hipotesis antara Corporate Social Responsibility dan Return On Asset

$\mathrm{H}_{0}$ : Corporate Social Responsibility tidak berpengaruh signifikan terhadap perubahan Return on Asset

$\mathrm{H}_{1}$ : Corporate Social Responsibility berpengaruh signifikan terhadap perubahan Return on Asset

b. Hipotesis antara Corporate Social Responsibility dan Return On Equity

$\mathrm{H}_{0}$ : CSR tidak berpengaruh signifikan terhadap perubahan ROE

$\mathrm{H}_{2}$ : CSR berpengaruh signifikan terhadap perubahan ROE

\section{HASIL PENELITIAN DAN PEMBAHASAN}

\subsection{Hasil Penelitian}

Pada penelitian saat ini penulis menggunakan populasi perusahaan-perusahaan yang termasuk dalam kelompok manufaktur yang tercantum pada Bursa Efek Indonesia (BEI) dengan periode tahun 2013 - 2017. Perusahaan manufaktur yang telah tercatat di Bursa Efek Indonesia secara konsisten dan tidak delisting untuk periode 2013-2017 terdapat 129 perusahaan. sebanyak 48 perusahaan tidak mempublikasikan laporan keuangan tahunan dan/atau annual report dan laporan keuangan tahnan secara berurutan untuk tahunn 20132017, 3 perusahaan manufaktur yang mempunyai laporan keuangan tahunan yang tidak diakhiri setiap 31 Desember secara konsisten untuk periode 2013-2017, 16 perusahaan tidak menggunakan mata uang rupiah dalam laporan keuangannya secara konsisten untuk periode 
2013-2017, dan sebanyak 3 perusahaan yang tidak mengungkapkan tanggung jawab sosial secara konsisten untuk periode 2013-2017. Tersisa 59 perusahaan yang akan digunakan sebagai sampel dalam penelitian ini.

\section{Analisis Statistik}

Tabel 1. Analisis Statistik Deskriptif

\begin{tabular}{crrrrr}
\hline & n & Minimum & Maximum & \multicolumn{1}{c}{ Mean } & Std. Deviation \\
\hline CSR & 295 & 0.1795 & 0.5641 & 0.3231 & 0.0765 \\
ROA & 295 & -19.07 & 71.51 & 6.7660 & 9.6214 \\
ROE & 295 & -233.71 & 135.85 & 10.3198 & 25.0027 \\
Valid N (listwise) & 295 & & & & \\
\hline
\end{tabular}

Sumber: Hasil Pengolahan Data SPSS Versi 24

Uji Asumsi Klasik. Uji ini mencakup uji normalitas, uji heteroskedastisitas, uji multikolinearitas, serta uji autokorelasi.

Tabel 2. Hasil Uji Normalitas

\begin{tabular}{lll}
\hline & Asymp. Sig. (2-tailed) \\
\hline ROA & 0.000 \\
ROE & 0.000 \\
\hline
\end{tabular}

Sumber : Hasil Pengelolaan data SPSS Versi 24

Tabel 3. Hasil Uji Multikolinearitas

\begin{tabular}{lccc}
\hline & Variabel & Tolerance & VIF \\
\hline Return on Asset & 1,000 & 1,000 \\
Return on Equity & 1,000 & 1,000 \\
\hline
\end{tabular}

Sumber : Hasil Pengelolaan data SPSS Versi 24

\section{Uji Heteroskedastisitas}
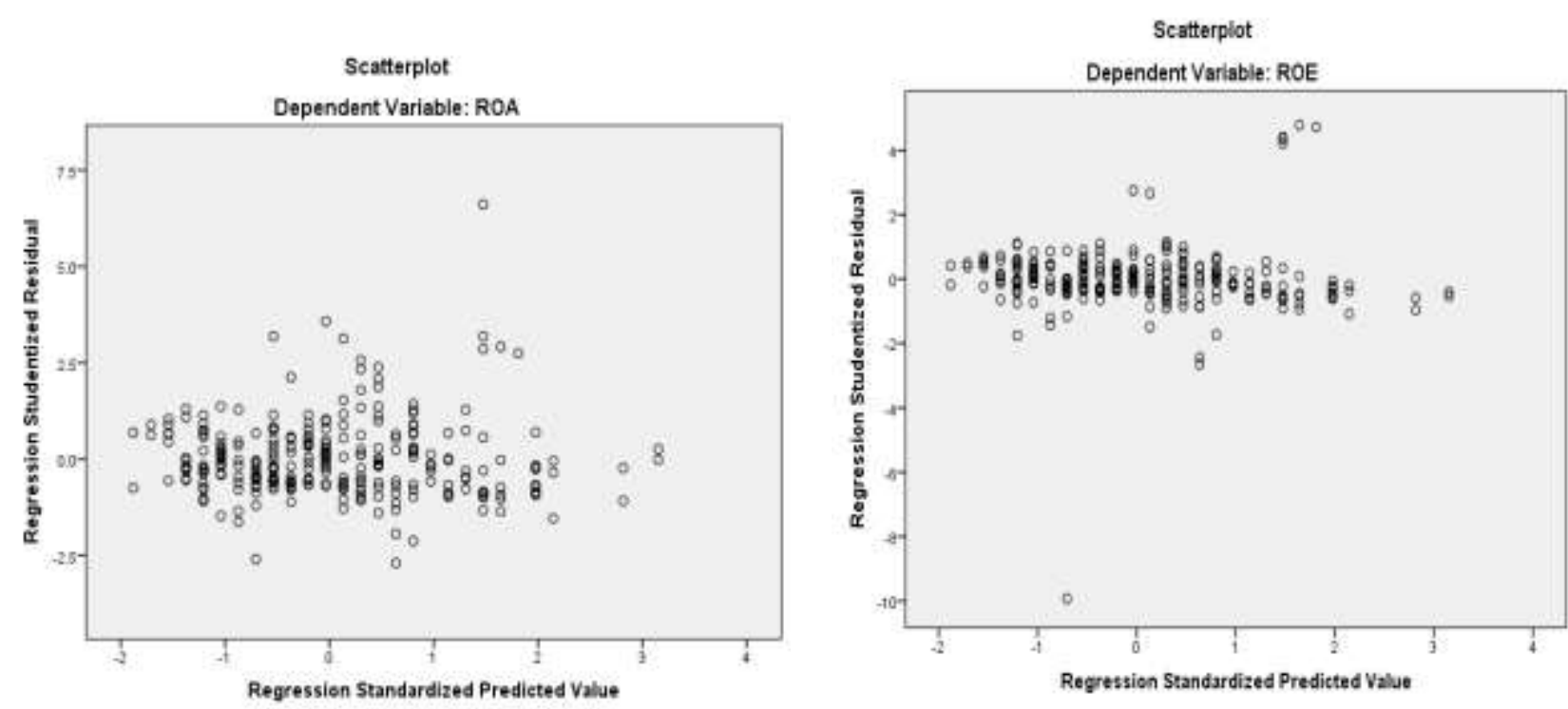
Tabel 4. Hasil Uji Autokorelasi

\begin{tabular}{ccc}
\hline Model & Signifikan & Kesimpulan \\
\hline CSR terhadap ROA & 1,841 & Tidak terdapat autokorelasi \\
CSR terhadap ROE & 1,943 & Tidak terdapat autokorelasi \\
\hline
\end{tabular}

Sumber : Hasil Pengolahan data SPSS Ver 24

Uji Regresi Linier Sederhana

a. Pengaruh Corporate Social Responsibility terhadap Return On Asset

Tabel 5. Hasil Uji Regresi Linier Sederhana

\begin{tabular}{ccc}
\hline Variabel Dependen & Variabel Independen & Koefisien Regresi $(\boldsymbol{\beta})$ \\
\hline ROA & CSR & 37,888 \\
Konstanta $(\boldsymbol{\alpha})=-5,476$ & & \\
\hline$S u m b e r: H a s i l$ Pengelolacin & &
\end{tabular}

Sumber : Hasil Pengelolaan data SPSS Versi 24

Kesimpulan pada table diatas dapat diaplikasikan pada model regresi dibawah ini:

ROA = -5,476 + 37,888 CSR+e

Dapat dilihat bahwa nilai konstanta senilai $-5,476$ memperlihatkan bahwa jika variabel Corporate Social Responsibility tidak menghadapi pengurangan atau mempunyai nilai 0, lalu ROA akan mempunyai nilai konstanta senilai $-5,476$. Koefisien $\beta=37,888$, artinya bahwa setiap pertambahan $1 \%$ pada CSR, maka ROA hendak terjadi peningkatan senilai $37,888 \%$. Jikalau koefisien regresi nilainya bersifat (+), bisa dinyatakan kalau CSR memiliki pengaruh positif kepada ROA.

b. Pengaruh CSR terhadap ROE

Tabel 6. Hasil Uji Regresi Linier Sederhana

\begin{tabular}{ccc}
\hline Variabel Dependen & Variabel Independen & Koefisien Regresi $(\boldsymbol{\beta})$ \\
\hline ROE & CSR & 85,570 \\
Konstanta $(\boldsymbol{\alpha})=-17,330$ & & \\
\hline
\end{tabular}

Sumber : Hasil Pengelolaan data SPSS Versi 24

Kesimpulan pada table diatas dapat diaplikasikan pada model regresi dibawah ini:

ROE $=-\mathbf{1 7 , 3 3 0}+\mathbf{8 5 , 5 7 0 ~ C S R + e ~}$

Dapat dilihat bahwa nilai konstanta senilai -17,330 memperllihatkan bahwa jika variabel Corporate Social Responsibility tidak menghadapi pengurangan atau mempunyai nilai 0, lalu ROE akan mempunyai nilai konstanta senilai $-17,330$. Koefisien $\beta=85,570$, artinya bahwa setiap pertambahan $1 \%$ pada CSR, maka ROA hendak terjadi peningkatan senilai $85,570 \%$. Jikalau koefisien regresi nilainya bersifat (+), bisa dinyatakan kalau CSR memiliki pengaruh positif kepada ROE.

Uji Hipotesis, Analisis Koefisien Korelasi (R) dan Koefisien Determinasi $\left(\mathbf{R}^{\mathbf{2}}\right)$

Tabel 7. Hasil uji R dan uji $\mathbf{R}^{2}$

\begin{tabular}{ccc}
\hline Model & $\mathbf{R}$ & \\
\hline CSR terhadap ROA & $0,301^{\mathrm{a}}$ & 0,091 \\
CSR terhadap ROE & $0,262^{\mathrm{a}}$ & 0,068 \\
\hline
\end{tabular}

Sumber : Hasil Pengolahan data SPSS Ver 24 
Uji Signifikan Parsial (Uji T). Berikut ini merupakan hasil uji t yang ditunjukkan tabel 8.

Tabel 8. Hasil Uji t

\begin{tabular}{cccc}
\hline Variabel & T-Hitung & Signifikan & Keputusan terhadap H0 \\
\hline CSR terhadap ROA & 5,404 & 0,000 & Tidak berpengaruh \\
CSR terhadap ROE & 4,641 & 0,000 & Tidak berpengaruh \\
\hline
\end{tabular}

Sumber : Hasil Pengolahan data SPSS Ver 24

Perhitungan t-tabel :

T-tabel $\quad=(\mathrm{a} / 2 ; \mathrm{n}-\mathrm{k}-1)$

$=(0,05 / 2 ; 59-1-1)$

$=(0,025 ; 57)$

T-tabel $\quad=2,002$ (distribusi nilai t-tabel)

Berdasarkan tabel dan data tersebut dapat dilihat nilai t hitung variabel pertama senilai 5,404

$>\mathrm{t}$ tabel 2,002 dan signifikansi senilai $0,000<0,05$. Dan dapat diambil kesimpulan yaitu HO ditolak dan $\mathrm{Hl}$ diterima. Itu berarti CSR mempunyai pengaruh yang signifikan kepada ROA. Begitu pula dengan nilai t-hitung pengaruh CSR terhadap ROE 4,641 > t tabel 2,002 dan signifikansi $0,000<0,05$. Dapat diambil kesimpulan yaitu HO ditolak dan Hl diterima. Itu berarti CSR mempunyai pengaruh yang signifikan kepada ROE.

\subsection{Pembahasan}

Pengaruh Penerapan Corporate Social Responsibility Terhadap Return on Asset. Berdasarkan hasil analisis statistik yang telah dilakukan dalam penelitian ini ditemukan bahwa hipotesis 1 berpengaruh signifikan terhadap return on asset. Dapat dilihat dari nilai signifikansinya yaitu 0,000 dan nilai t-hitung $=5,404$. Dalam hal ini t hitung nilainya lebih tinggi daripada nilai t tabel dan sig lebih rendah daripada 0,05 maka dari itu terbukti apabila corporate social responsibility mempunyai pengaruh yang signifikan kepada ROA. Dampak antara penerapan CSR dengan ROA adalah semakin banyak pengungkapan yang dilakukan perusahaan maka akan meningkatkan kepercayaan masyarakat terhadap produk perusahaan, sehingga reputasi perusahaan juga meningkat di mata masyarakat. Hal ini konsisten dengan teori yang dikemukakan Herry (2013 : 139) yaitu CSR merupakan komitmen suatu perusahan untuk memberikan dedikasi jangka yang panjang kepada suatu persoalan tertentu dalam lingkungan atau masyarakat agar supaya menghasilkan suatu lingkungan lebih baik dari sebelumnya. Hal inilah yang membuat perusahaan-perusahaan berlomba-lomba untuk membuat perusahaan lebih dikenal masyarakat melalui kegiatan CSR dalam perusahan.

Pengaruh Penerapan Corporate Social Responsibility Terhadap Return on Equity. Berdasarkan hasil statistik yang dilakukan dalam penelitian ini ditemukan bahwa hipotesis 2 berpengaruh signifikan terhadap return on equity. Dapat dilihat dari nilai signifikansinya yaitu 0,000 dan nilai t-hitung $=4,641$. Dalam hal ini nilai t hitung lebih tinggi daripada nilai $t$ tabel dan nilai sig lebih rendah daripada 0,05 maka dari itu terbukti apabila corporate social responsibility mempunyai pengaruh yang signifikan kepada ROE. Dampak antara penerapan CSR dengan ROE adalah semakin banyak pengungkapan corporate social responsibility yang dilakukan oleh perusahaan maka return on equti akan semakin meningkat. Pengungkapan yang semakin luas dapat memperbanyak informasi yang diterima oleh para pemegang saham perusahaan (shareholder) ataupun kepada beberapa pihak yang mempunyai kepentingan pada perusahan (Stake-holder) sehingga mereka akan lebih mempercayakan modal mereka untuk ditanamkan dalam perusahaan tersebut dan dapat mempermudah perusahaan memakai dana itu untuk kegiatan perusahan untuk menaikkan tingkat keuntungan. Hal ini konsisten dengan teori yang dikemukakan oleh Tandelilin (2001:240) bahwa kinerja perusahan bisa dinilai melalui ROE yang adalah satu dari beberapa indeks atau 
indicator yang sangat berharga bagi para investor dalam memberikan nilai perspektif perusahan pada masa yang akan datang yaitu dengan cara melihat perkembangan profitabilitas perusahan. hal-hal tersebut cukup untuk menjelaskan kenapa perusahaan memperoleh kepercayaan dari shareholder dan stakeholder, yaitu dengan meningkatkan pengungkapan corporate social responsibility perusahaan.

\section{KESIMPULAN DAN SARAN}

\subsection{Kesimpulan}

Menurut hasil analitis dan pengujian yang telah dilakukan terhadap 59 perusahan manufaktur yang terdaftar di Bursa Efek Indonesia selama periode 2013-2017 dalam penelitian pengaruh penerapan Corporate Social Responsibility terhadap profitabilitas, maka diperoleh kesimpulan dibawah ini:

1. Menurut data yang telah diuji dapat diketahui bahwa Corporate Social Responsibility memiliki pengaruh yang signifikan kepada profitabilitas perusahan diukur menggunakan rasio Return on Asset. Maka dari itu bisa diambil kesimpulan yaitu pengujian hipotesis yang telah dilakukan dinyatakan bahwa Corporate Social Responsibility memiliki pengaruh yang signifikan kepada Return on Asset bisa diterima. Dalam hal ini memperlihatkan bahwa jikalau perusahaan melakukan pengungkapan kegiatan tanggungjawab sosial yang banyak pada laporan keuangan tahunan maka profitabilitas perusahaan juga akan meningkat. Hal ini konsisten dengan hasil penelitian yang telah diteliti oleh Fitria Ayuning (2014).

2. Menurut data yang telah diuji dapat diketahui bahwa Corporate Social Responsibility memiliki pengaruh yang signifikan kepada profitabilitas perusahaan diukur menggunakan rasio Return on Equity. Maka dari itu bisa diambil kesimpulan yaitu pengujian hipotesis yang telah dilakukan dinyatakan bahwa Corporate Social Responsibility memiliki pengaruh yang signifikan kepada Return on Equity bisa diterima. Dalam hal ini memperlihatkan bawha jikalau perusahaan melakukan pengungkapan kegiatan tanggungjawab sosial yang banyak pada laporan keuangan tahunan maka profitabilitas perusahaan juga akan meningkat. Hal ini konsisten dengan hasil penelitian yang telah diteliti oleh Fitria Ayuning (2014).

Berikut ini merupakan kelemahan dan keterbatasan yang dialami, yaitu:

1. Peneliti hanya memperoleh data yang berhubungan dengan Corporate Social Responsibility yang dilakukan perusahaan dari laporan keuangan tahunan yang dipublikasi oleh perusahan.

2. Jumlah item pengungkapan CSR yang digunakan untuk variabel independen menggunakan indeks Sembiring (2005) yaitu sebanyak 78 item pengungkapan dan terdapat unsur subyektifitas yang menyebabkan kemungkinan adanya item yang terlewati saat pengamatan.

\subsection{Saran}

Menurut beberapa keterbatasan penelitian, penulis memberikan rekomendasi untuk penelitian-penelitian berikutnya yaitu:

1. Penelitian berikutnya sebaiknya memperoleh data terkait CSR tidak hanya dari laporan tahunan, melainkan melihat laporan lainya yang terdapat pada surat kabar cetak maupun elektronik.

2. Penelitian selanjutnya perlu memperbarui item-item pengungkapan sesuai perkembangan untuk digunakan dalam menilai pengungkapan CSR, misalnya item pengungkapan berdasarkan GRI 4.0. 


\section{DAFTAR PUSTAKA}

Filemon, Astrie. 2014. Pengaruh CSR Terhadap ROA Pada Perusahaan Telekomunikasi di Bursa Efek Indonesia. Jurnal Manajemen Indonesia, Vol.14, No.3:223-232

Fitria Ayuning P, Darminto, Dwiatmanto. 2014. Pengaruh CSR Terhadap Profitabilitas Perusahaan. Jurnal Administrasi Bisnis (JAB), Vol.13, No. 1: 1-10

Halim, Abdul.2013. Akuntansi Manajemen. Edisi Kedua. Penerbit BPFE, Yogyakarta.

Priyatno Duwi. 2016. Belajar Alat Analisis Data dan Cara Pengolahannya Dengan SPSS. Cetakan 1, Penerbit Gava Media

Rifqiyah Rina F, 2016. Pengaruh Ukuran Perusahaan, Profitabilitas, dan Kepemilikan Saham Publik Terhadap Pengungkapan CSR. Sekolah Tinggi Ilmu Ekonomi Perbanas. Surabaya

Riwayadi, Drs.,MBA.,CA.,Ak.,CSRS, 2014, Akuntansi Biaya : Pendekatan Tradisional dan Kontemporer, Penerbit Salemba Empat

Sugiono. 2016. Metode Dalam Penelitian Kualitatif, Kuantitatif dan R\&D. Bandung : PT Alfabet.

Tandelilin. 2001 . Manajemen Portofolio dan Analisis Investasi. Yogyakarta : BPFE

Wiratna Sujarweni V. 2016. Akuntansi Manajemen, Teori dan Aplikasi, Penerbit Pustaka Baru Press

https://idx.co.id 